\title{
IA $\boldsymbol{B S}_{\mathrm{S}}$ \\ Genocide Studies and Prevention: An International

November 2013

\section{Table of Contents}

Follow this and additional works at: https://digitalcommons.usf.edu/gsp

\section{Recommended Citation}

(2013) "Table of Contents," Genocide Studies and Prevention: An International Journal: Vol. 8: Iss. 1: Article 1.

Available at: https://digitalcommons.usf.edu/gsp/vol8/iss1/1

This Front Matter is brought to you for free and open access by the Open Access Journals at Digital Commons @ University of South Florida. It has been accepted for inclusion in Genocide Studies and Prevention: An International Journal by an authorized editor of Digital Commons @ University of South Florida. For more information, please contact digitalcommons@usf.edu. 
ISSN 1911-0359

eISSN 1911-9933

\section{Genocide Studies and Prevention: An International Journal}

Genocide Studies: Debates from the Latin American Margin

Volume 8.1 - 2013 
○2013 Genocide Studies and Prevention 8, no. 1 


\section{Genocide Studies and Prevention: An International Journal}

http://scholarcommons.usf.edu/gsp/

\section{Volume 8.1 - 2013}

Genocide Studies: Debates from the Latin American Margin

\section{GSP Interim Editorial Board}

Editorial

Daniel Feierstein .3

Marcelo Ferreira

\section{Articles}

Genocide, and its Definition as the "Partial Elimination of a National Group".

Antonio Miguez Macho

A Genealogy of Genocide in Francoist Spain

Lucrecia Molinari

Counterinsurgency and Union Movement in El Salvador (1967-1968)

\section{Lior Zylberman}

Narrative Strategies of Post-Genocide Argentine Filmmaking:

The Decade of the 1980s

\section{Documents}

María Belén Riveiro, Luciana Rosende and Lior Zylberman

Genocide on Trial: Case Note and Extracts of "Circuito Camps" Judgment

\section{Book Reviews}

Totally Unofficial: The Autobiography of Raphael Lemkin,

edited by Donna-Lee Frieze, reviewed by Douglas Irvin-Erickson

Yang Jisheng, Tombstone: The Great Chinese Famine 1958-1962,

reviewed by Ernesto Verdeja . .71

\section{Contributors}

